\title{
Case report: failure under azithromycin treatment in a case of bacteremia due to Salmonella enterica Paratyphi A
}

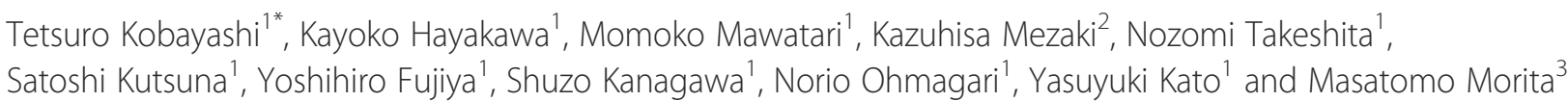

\begin{abstract}
Background: Limited information is available regarding the clinical efficacy of azithromycin for the treatment of enteric fever due to fluoroquinolone-resistant Salmonella Typhi and Salmonella Paratyphi among travelers returning to their home countries.

Case presentation: We report a case of a 52-year-old Japanese man who returned from India, who developed a fever of $39^{\circ} \mathrm{C}$ with no accompanying symptoms 10 days after returning to Japan from a 1-month business trip to Delhi, India. His blood culture results were positive for Salmonella Paratyphi A. He was treated with 14 days of ceftriaxone, after which he remained afebrile for 18 days before his body temperature again rose to $39^{\circ} \mathrm{C}$ with no apparent symptoms. He was then empirically given $500 \mathrm{mg}$ of azithromycin, but experienced clinical and microbiological failure of azithromycin treatment for enteric fever due to Salmonella Paratyphi A. However, the minimum inhibitory concentration (MIC) of azithromycin was not elevated $(8 \mathrm{mg} / \mathrm{L})$. He was again given ceftriaxone for 14 days with no signs of recurrence during the follow-up.

Conclusion: There are limited data available for the treatment of enteric fever using azithromycin in travelers from developed countries who are not immune to the disease, and thus, careful follow-up is necessary. In our case, the low azithromycin dose might have contributed the treatment failure. Additional clinical data are needed to determine the rate of success, MIC, and contributing factors for success and/or failure of azithromycin treatment for both Salmonella Typhi and Salmonella Paratyphi infections.
\end{abstract}

Keywords: Salmonella Paratyphi, Enteric fever, Azithromycin, Treatment failure, Returned traveler

\section{Background}

Salmonella enterica Typhi and Salmonella enterica Paratyphi A, B, and C are the causative pathogens of enteric fever in tropical and subtropical countries such as southern and southeast Asia and Africa [1], and fluoroquinoloneresistant strains of Salmonella Typhi and Salmonella Paratyphi A have recently emerged in these countries [2]. In developed countries, these strains cause enteric fever in travelers returning from the endemic areas [3]. Azithromycin and the third-generation cephalosporins (e.g., ceftriaxone) are the drugs of choice for treatment

\footnotetext{
*Correspondence: tootsieroll-29@umin.ac.jp

'Disease Control and Prevention Center, National Center for Global Health and Medicine, Shinjuku-ku Toyama 1-21-1, 162-8655 Tokyo, Japan Full list of author information is available at the end of the article
}

of fluoroquinolone-resistant Salmonella Typhi and Salmonella Paratyphi [4]. However, the azithromycin breakpoints for Salmonella Typhi and Salmonella Paratyphi A have not been defined by the Clinical and Laboratory Standard Institutions (CLSI) or the European Committee on Antimicrobial Susceptibility Testing (EUCAST) criteria $[5,6]$. The number of studies regarding the clinical efficacy of azithromycin for the treatment of enteric fever is still limited, and to our knowledge, all of them were conducted in endemic areas [7-11]. Here, we report a case of azithromycin treatment failure in a Japanese man with Salmonella Paratyphi A infection who returned from travel.

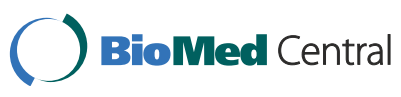

C 2014 Kobayashi et al.; licensee BioMed Central Ltd. This is an Open Access article distributed under the terms of the Creative Commons Attribution License (http://creativecommons.org/licenses/by/4.0), which permits unrestricted use, distribution, and reproduction in any medium, provided the original work is properly credited. The Creative Commons Public Domain Dedication waiver (http://creativecommons.org/publicdomain/zero/1.0/) applies to the data made available in this article, unless otherwise stated. 


\section{Case presentation}

A 52-year-old Japanese man developed a fever of $39^{\circ} \mathrm{C}$ with no accompanying symptoms 10 days after returning to Japan from a 1-month business trip to Delhi, India. He presented to a local clinic 5 days after the fever developed. Blood cultures grew with Gram-negative rods (GNR) after 3 days, which were subsequently identified as Salmonella Paratyphi A with unknown antibiotic susceptibility. The patient was transferred to our hospital to complete his 14-d therapy with ceftriaxone ( $2 \mathrm{~g}$ daily). He was afebrile for 18 days following the completion of the antibiotic therapy, after which his body temperature rose to $39^{\circ} \mathrm{C}$ with no apparent symptoms. He presented to our hospital on Day 3 of the second fever. A blood culture was performed, and the patient was empirically treated with oral azithromycin (500 mg daily) owing to a suspected relapse of enteric fever. The patient was compliant with the oral antibiotic regimen. As the blood culture results showed GNR growth in 2 days, he was readmitted to our hospital for further treatment. We continued azithromycin treatment under direct observation by the medical staff for a total of 7 days. GNR was again identified as Salmonella Paratyphi A, which was found to be susceptible to ceftriaxone (minimum inhibitory concentration $[\mathrm{MIC}], 0.12 \mathrm{mg} / \mathrm{L}$ ), resistant to nalidixic acid, and showed decreased susceptibility to ciprofloxacin (MIC, $0.5 \mathrm{mg} / \mathrm{L}$ ). The MIC's for azithromycin were $8 \mathrm{mg} / \mathrm{L}$ and $16 \mathrm{mg} / \mathrm{L}$, as determined in a reference laboratory using the E-test (Biomerieux Co. Ltd., Tokyo, Japan) and broth micro dilution (BMD), respectively.

Despite the uninterrupted 7 days of oral azithromycin treatment under direct observation, the patient remained febrile until the final day of the regimen. Another blood culture was performed, and the treatment was switched to ceftriaxone because of suspected azithromycin treatment failure. The blood culture showed GNR growth, which was again identified as Salmonella Paratyphi A with the same MICs for ceftriaxone, ciprofloxacin, and azithromycin as the initial culture results. Fluorodeoxyglucose positron emission tomography (FDG- PET) showed slightly thickened intestinal wall of the colon. However, no other inflammatory focuses suggesting deep-seeded infection, such as abscesses and aortitis, were detected. The abdominal ultrasound showed no intra-abdominal abscess on the thickened intestinal wall. The patient defervesced on Day 3 of ceftriaxone, and the result of the follow-up blood culture performed on Day 4 of ceftriaxone therapy yielded no growth. After completion of 14 days of antibiotic treatment, the patient was discharged with no signs of recurrence during the follow-up.

\section{Discussion}

Enteric fever due to nalidixic acid-resistant Salmonella Typhi and/or Salmonella Paratyphi A is generally treated with ceftriaxone or azithromycin [12,13] with previous reports demonstrating the efficacy of azithromycin in the treatment of enteric fever [7-9]. Moreover, the probability of recurrence is $<3 \%$ when treated with azithromycin compared to $3-6 \%$ when treated with ceftriaxone. Therefore, treatment with azithromycin may be preferred for quinolone-resistant Salmonella Typhi and Salmonella Paratyphi A [8,14]. However, data are currently only available for endemic regions of enteric fever where immunity to the disease may contribute to the high success rates.

To the best of our knowledge, there has only been fewcase reports of treatment failure with azithromycin for Salmonella Paratyphi A. In one report, the MIC for azithromycin was $>64 \mathrm{mg} / \mathrm{L}$, which was assumed to be azithromycin-resistant; however, the exact mechanism of resistance has not been defined [15]. In another report, a case of recurrent, multifocal Salmonella enterica serotype Paratyphi A breast abscesses was presented which relapsed despite surgery and multiple courses of antibiotics, including co-trimoxazole and azithromycin [16]. Although the bioavailability of oral azithromycin was reported to be approximately $37 \%$, which is lower than that for fluoroquinolones, it has been suggested that the intracellular concentration of azithromycin is 50-100 times greater than that in serum and that the bactericidal effect remains stable regardless of a high MIC $[17,18]$. The recent CLSI guidelines and the EUCAST criteria do not specify the MIC for azithromycin when treating Salmonella Typhi or Salmonella Paratyphi A [5,6]. However, the EUCAST states that the wild-type isolates of Salmonella Typhi have an MIC $\leq 16 \mathrm{mg} / \mathrm{L}$ [6]. In a study conducted in India, the MIC distributions for Salmonella Typhi and Salmonella Paratyphi A ranged from 0.0612 to $64 \mathrm{mg} / \mathrm{L}$ and from 1 to $32 \mathrm{mg} / \mathrm{L}$, respectively, and the MIC90 values were $24 \mathrm{mg} / \mathrm{L}$ for both serovars [19]. Recent report on MIC distribution of typhoidal Salmonella isolates of returned travelers showed that azithromycin MICs were 2-256 $\mu \mathrm{g} / \mathrm{mL}$ among the 354 isolates, and a minority of the S. Paratyphi A isolates showed an MIC $\leq 8 \mathrm{mg} / \mathrm{L}$ [20].

In the present case, we experienced clinical and microbiological treatment failure with azithromycin for enteric fever due to Salmonella Paratyphi A despite the fact that the MIC for azithromycin was not elevated $(8 \mathrm{mg} / \mathrm{L}$ by E-test and $16 \mathrm{mg} / \mathrm{L}$ by BMD). Previous studies evaluated the efficacy of azithromycin therapy used various regimens as summarized in Table 1. Most of the dosages used ranged from $10 \mathrm{mg} / \mathrm{kg}$ to $20 \mathrm{mg} / \mathrm{kg}$. A review published in 2005 recommends $8-10 \mathrm{mg} \cdot \mathrm{kg}^{-1} \cdot \mathrm{dose}^{-1}$ azithromycin for enteric fever caused by either Salmonella Typhi or Salmonella Paratyphi A [12]. Owing to the patient's weight $(80 \mathrm{~kg})$ at the time of admission, $500 \mathrm{mg}$ of azithromycin [13], which was $6.25 \mathrm{mg} / \mathrm{kg}$, might have been an inadequate dose when compared to previously recommended doses. Further studies are necessary in 
Table 1 Reported efficacy of azithromycin for treatment of Salmonella Typhi and Salmonella Paratyphi

\begin{tabular}{|c|c|c|c|c|c|c|c|c|}
\hline Author, year & Country & Patients population & Azithromycin dose & $\begin{array}{l}\text { Body weights of } \\
\text { patients }(\mathrm{kg})\end{array}$ & Route of administration & Efficacy & MIC of isolates, $g / L^{*}$ & References \\
\hline Girgis, 1999 & Egypt & $\begin{array}{l}n=36, \text { mean age (range): } \\
19.6(18-30)\end{array}$ & $\begin{array}{l}1 \mathrm{~g} / \text { day on the first day, } \\
\text { followed by } 500 \mathrm{mg} / \text { day } \\
\text { on the next } 6 \text { days }\end{array}$ & NA & Oral & Clinical cure rate: $100 \%$ & $\mathrm{BMD} \mathrm{MIC}_{90}^{*}$ (range): 8 (4-16) & [9] \\
\hline Butler, 1999 & India & $\begin{array}{l}n=42, \text { mean age (range): } \\
26.2(17-53)\end{array}$ & $500 \mathrm{mg} /$ day for 7 days & $\begin{array}{l}\text { Mean } 52.2 \\
\text { (range: } 40-74 \text { ) }\end{array}$ & Oral & $\begin{array}{l}\text { Clinical cure rate: } 88 \% \\
\text { (within } 8 \text { days), 100\% } \\
\text { (within } 14 \text { days) }\end{array}$ & BMD MIC* $_{90}$ (range): 16 (4-32) & [7] \\
\hline Chinh, 2000 & Vietnam & $\begin{array}{l}n=44, \text { mean age (range): } \\
26.6(15-68)\end{array}$ & $1 \mathrm{~g} /$ day for 5 days & $\begin{array}{l}\text { Mean } 47.3 \\
\text { (range: } 34-60 \text { ) }\end{array}$ & Oral & Clinical cure rate: $95.5 \%$ & E-test, $\mathrm{MIC}_{90}$ (range): 8 (4-16) & {$[10]$} \\
\hline Parry, 2007 & Vietnam & $\begin{array}{l}n=62, \text { mean age (range): } \\
10.5(4-42)\end{array}$ & $\begin{array}{l}10 \mathrm{mg} / \mathrm{kg} / \text { day for } \\
7 \text { days }\end{array}$ & $\begin{array}{l}\text { Mean } 24 \text { (range: } \\
12-58 \text { ) }\end{array}$ & Oral & Clinical cure rate: $82 \%$ & E-test $\mathrm{MIC}_{90}$ (range): 16 (4-32) & [8] \\
\hline Dolecek, 2008 & Vietnam & $\begin{array}{l}\mathrm{n}=142 \text {, median age } 11 \mathrm{yrs}, \\
\text { (range } 1-41 \text { ) }\end{array}$ & $\begin{array}{l}20 \mathrm{mg} / \mathrm{kg} / \text { day for } \\
7 \text { days }\end{array}$ & $\begin{array}{l}\text { Median } 24.5 \\
(9.5-57)\end{array}$ & Oral & Treatement failure: $9.3 \%$ & E-test, $\mathrm{MIC}_{90}$ (range): 12 (4-16) & [1 1 1] \\
\hline
\end{tabular}

Abbreviations: BMD broth microdilution, MIC Minimum inhibitory concentrations, NA data not available.

${ }^{*} \mathrm{MIC}_{90}$ were determined based on the data provided in refeneces. 
terms of optimal route of administration, and appropriate dose and duration especially among returned travelers who are not immune to typhoid.

In this case, no infectious focus such as arteritis or abscesses was detected by the PET-CT scan and abdominal sonography. We suspected that the thickening of intestinal wall of the colon might be due to the hypertrophy of Peyer's patches; one of the classic presentations observed in cases of enteric fever due to Salmonella Typhi or Salmonella Paratyphi [21].

\section{Conclusions}

There are limited data available for the treatment of enteric fever using azithromycin in travelers from developed countries who are not immune to the disease, and thus, careful follow-up is necessary. Additional clinical data are needed to determine the rate of success, MIC, and contributing factors for success and/or failure of azithromycin treatment for both Salmonella Typhi and Salmonella Paratyphi.

\section{Consent}

Written informed consent was obtained from the patient for the publication of this case report. A copy of the written consent is available for review by the Editor of this journal.

\section{Competing interests}

The authors declare that they have no competing interests.

\section{Authors' contributions}

TK was responsible for drafting the manuscript, and clinical management of the case. $\mathrm{KH}$ and $\mathrm{YK}$ supervised the work and helped to draft the manuscript. KM participated in the microbiological work-ups. MM, NT, SK, YF, SK, and NO were responsible for clinical management of the case. All authors have read the manuscript and accepted the final version.

\section{Financial support}

This work was partly supported by funding from the Research on Emerging and Re-emerging Infectious Diseases by the Ministry of Health, Labor, and Welfare, Japan (H24-shinkou-ippan-013).

\section{Author details}

${ }^{1}$ Disease Control and Prevention Center, National Center for Global Health and Medicine, Shinjuku-ku Toyama 1-21-1, 162-8655 Tokyo, Japan.

${ }^{2}$ Microbiology Laboratory, National Center for Global Health and Medicine, Shinjuku-ku Toyama 1-21-1, 162-8655 Tokyo, Japan. ${ }^{3}$ National Institute of Infectious Diseases, Shinjuku-ku Toyama 1-23-1, Tokyo, Japan.

Received: 18 March 2014 Accepted: 3 July 2014

Published: 20 July 2014

\section{References}

1. Crump JA, Luby SP, Mintz ED: The global burden of typhoid fever. Bull World Health Organ 2004, 82:346-353.

2. Humphries RM, Fang FC, Aarestrup FM, Hindler JA: In vitro susceptibility testing of fluoroquinolone activity against Salmonella: recent changes to CLSI standards. Clin Infect Dis 2012, 55:1107-1113.

3. Leder K, Torresi J, Libman MD, Cramer JP, Castelli F, Schlagenhauf P, WilderSmith A, Wilson ME, Keystone JS, Schwartz E, Barnett ED, von Sonnenburg F, Brownstein JS, Cheng AC, Sotir MJ, Esposito DH, Freedman DO, GeoSentinel Surveillance Network: GeoSentinel surveillance of illness in returned travelers, 2007-2011. Ann Intern Med 2013, 158:456-468.

4. Threlfall EJ, de Pinna E, Day M, Lawrence J, Jones J: Alternatives to ciprofloxacin use for enteric fever, United Kingdom. Emerg Infect Dis 2008, 14:860-861.
5. Clinical and Laboratory Standards Institute: M100-23 Performance Standards for Antimicrobial Susceptibility Testing. 2013, Twenty-Third Informational Supplement. Wayne, PA.

6. The European Committee on Antimicrobial Susceptibility Testing (EUCAST): Breakpoint Tables for Interpretation of MICs and Zone Diameters Version 3.1. 2013. Available at: [http://www.eucast.org/fileadmin/src/media/PDFs/ EUCAST_files/Breakpoint_tables/Breakpoint_table_v_3.1.pdf]. Accessed February 12, 2014.

7. Butler T, Sridhar CB, Daga MK, Pathak K, Pandit RB, Khakhria R, Potkar CN, Zelasky MT, Johnson RB: Treatment of typhoid fever with azithromycin versus chloramphenicol in a randomized multicentre trial in India. J Antimicrob Chemother 1999, 44:243-250.

8. Parry CM, Ho VA, le Phuong T, Bay PV, Lanh MN, le Tung T, Tham NT, Wain J, Hien TT, Farrar JJ: Randomized controlled comparison of ofloxacin, azithromycin, and an ofloxacin-azithromycin combination for treatment of multidrug-resistant and nalidixic acid-resistant typhoid fever. Antimicrob Agents Chemother 2007, 51:819-825.

9. Girgis NI, Butler T, Frenck RW, Sultan Y, Brown FM, Tribble D, Khakhria R: Azithromycin versus ciprofloxacin for treatment of uncomplicated typhoid fever in a randomized trial in Egypt that included patients with multidrug resistance. Antimicrob Agents Chemother 1999, 43:1441-1444.

10. Chinh NT, Parry CM, Ly NT, Ha HD, Thong MX, Diep TS, Wain J, White NJ, Farrar JJ: A randomized controlled comparison of azithromycin and ofloxacin for treatment of multidrug-resistant or nalidixic acid-resistant enteric fever. Antimicrob Agents Chemother 2000, 44(7):1855-1859.

11. Dolecek C, Tran TP, Nguyen NR, Le TP, Ha V, Phung QT, Doan CD, Nguyen TB, Duong TL, Luong BH, Nguyen TB, Nguyen TA, Pham ND, Mai NL, Phan VB, Vo AH, Nguyen VM, Tran TT, Tran TC, Schultsz C, Dunstan SJ, Stepniewska K, Campbell JI, To SD, Basnyat B, Nguyen W, Nguyen VS, Nguyen TC, Tran TH, Farrar J: A multi-center randomised controlled trial of gatifloxacin versus azithromycin for the treatment of uncomplicated typhoid fever in children and adults in Vietnam. PLoS One 2008, 3(5):e2188.

12. Bhan MK, Bahl R, Bhatnagar S: Typhoid and paratyphoid fever. Lancet 2005, 366:749-762.

13. Longo DL, Fauci AS, Kasper DL, Hauser SL, Jameson JL, Loscalzo J: Harrison's principles of internal medicine. In Enteric (Typhoid) Fever. Volume 2. 18th edition. New York: McGraw Hill; 2011:1277.

14. Effa EE, Lassi ZS, Critchley JA, Garner P, Sinclair D, Olliaro PL, Bhutta ZA: Fluoroquinolones for treating typhoid and paratyphoid fever (enteric fever). Cochrane Database Syst Rev 2011, (10) doi:10.1002/14651858. CD004530.pub4.

15. Molloy A, Nair S, Cooke FJ, Wain J, Farrington M, Lehner PJ, Torok ME: First report of Salmonella enterica serotype paratyphi A azithromycin resistance leading to treatment failure. J Clin Microbio/ 2010, 48:4655-4657.

16. Fernando S, Molland JG, Gottlieb T: Failure of oral antibiotic therapy, including azithromycin, in the treatment of a recurrent breast abscess caused by Salmonella enterica serotype Paratyphi A. Pathog Glob Health 2012, 106(6):366-369.

17. Foulds G, Luke DR, Teng R, Willavize SA, Friedman H, Curatolo WJ: The absence of an effect of food on the bioavailability of azithromycin administered as tablets, sachet or suspension. J Antimicrob Chemother 1996, 37:37-44.

18. Panteix G, Guillaumond B, Harf R, Desbos A, Sapin V, Leclercq M, Perrin-Fayolle M: In-vitro concentration of azithromycin in human phagocytic cells. J Antimicrob Chemother 1993, 31:1-4.

19. Capoor MR, Rawat D, Nair D, Hasan AS, Deb M, Aggarwal P, Pillai P: In vitro activity of azithromycin, newer quinolones and cephalosporins in ciprofloxacin-resistant Salmonella causing enteric fever. J Med Microbiol 2007, 56:1490-1494.

20. Hassing RJ, Goessens WH, van Pelt W, Mevius DJ, Stricker BH, Molhoek N, Verbon A, van Genderen PJ: Salmonella subtypes with increased MICs for azithromycin in travelers returned to The Netherlands. Emerg Infect Dis 2014, 20(4):705-708.

21. Kraus MD, Amatya B, Kimula Y: Histopathology of typhoid enteritis: morphologic and immunophenotypic findings. Mod Pathol 1999, 12(10):949-955.

doi:10.1186/1471-2334-14-404

Cite this article as: Kobayashi et al:: Case report: failure under azithromycin treatment in a case of bacteremia due to Salmonella enterica Paratyphi A. BMC Infectious Diseases 2014 14:404. 